\title{
Effects of Microbial Transformation on the Biological Activities of Prenylated Chalcones from Angelica keiskei
}

\author{
Yina Xiao and Ik-Soo Lee *
}

Citation: Xiao, Y.; Lee, I.-S. Effects of Microbial Transformation on the Biological Activities of Prenylated Chalcones from Angelica keiskei. Foods 2022, 11, 543. https://doi.org/ 10.3390 /foods 11040543

Academic Editors

Maria Eduardo-Figueira and João Rocha

Received: 27 January 2022

Accepted: 11 February 2022

Published: 14 February 2022

Publisher's Note: MDPI stays neutral with regard to jurisdictional claims in published maps and institutional affiliations.

Copyright: (C) 2022 by the authors. Licensee MDPI, Basel, Switzerland. This article is an open access article distributed under the terms and conditions of the Creative Commons Attribution (CC BY) license (https:// creativecommons.org/licenses/by/ $4.0 /)$.
College of Pharmacy, Chonnam National University, Gwangju 61186, Korea; yogurtxiao@163.com

* Correspondence: islee@chonnam.ac.kr; Tel.: +82-62-530-2932

\begin{abstract}
Microbial transformation is an alternative method for structural modification. The current study aimed at application of microbial transformation for discovering new derivatives and investigating the structure-activity relationship of isobavachalcone (1), 4-hydroxyderricin (2), and xanthoangelol (3) isolated from the herb Angelica keiskei. In the initial screening process, 1-3 were incubated with microbes using a two-stage fermentation method and analyzed through TLC monitoring. The screening results showed that Rhizopus oryzae and Mucor hiemalis were able to transform 1 and 2, respectively. Additionally, M. hiemalis and Mortierella ramanniana var. angulispora were able to transform 3. Following scale-up fermentation, four new $(4,5,7$, and 10) and five known $(6,8,9$, 11, and 12) metabolites were produced. Cytotoxicity of all the compounds (1-12) was investigated using three human cancer cell lines including A375P, HT-29, and MCF-7 by MTT method. Meanwhile, the tyrosinase inhibitory activity of 1-12 was evaluated using L-tyrosine as a substrate. Overall, 1 and 3 displayed the highest cytotoxicity, and 5 and 7 exhibited the most potent tyrosinase inhibitory activity with relatively low cytotoxicity. This allowed us to postulate that the introduction of $4^{\prime}$-O-glucopyranosyl group led to the reduction in cytotoxicity and improvement in tyrosinase inhibitory activity.
\end{abstract}

Keywords: Angelica keiskei; microbial transformation; isobavachalcone; 4-hydroxyderricin; xanthoangelol; cytotoxicity; tyrosinase inhibition

\section{Introduction}

Angelica keiskei (Umbelliferae) is a perennial leafy herb, mainly distributed in Asian countries, including Korea and Japan. The herb is named as 'Myeong-il yeob' in Korean and 'Ashitaba' in Japanese, both literally meaning tomorrow's leaves. Another prevalent name in Korean for A. keiskei is 'Sinsuncho' meaning the herb of eternal youth [1]. In daily life, it is drunk as a tea and cooked as a vegetable. Traditionally, it is consumed as medicinal herb with tonic, mild cathartic, diuretic, and galactagogue effects [2]. Preceding phytochemical investigations on $A$. keiskei revealed the presence of abundant prenylated chalcones in its leaves, stems, and roots [3]. These chalcones are proposed as effective agents for diverse health-beneficial properties such as anti-tumor [4], anti-inflammatory [5], anti-bacterial [6], anti-diabetic [7], anti-melanogenic [8], and anti-obesity [9] effects. Particularly, 4-hydroxyderricin (HD) and xanthoangelol (XT) are the predominant prenylchalcones in this herb, with relative abundances of $1.97 \%$ and $5.05 \%$, respectively [10]. HD and XT have been proposed as potent cytotoxic agents that promote apoptosis and suppress tumor-induced angiogenesis in cancer cells [11]. After surgically removing implanted tumors, the administration of HD or XT inhibited metastasis and increased overall survival in mice. They were considered as promising therapeutic agents for the treatment of melanoma [12,13]. Isobavachalcone (IBC) is another bioactive prenylchalcone isolated from A. keiskei [14]. Accumulative studies have demonstrated that IBC suppressed the proliferation and induced cell apoptosis in diverse cancer cell lines including colorectal cancer, liver cancer, breast cancer, leukemia, tongue squamous cell carcinoma [15]. Meanwhile, 
IBC demonstrated reduced cytotoxicity toward normal cells in comparison with cancer cells. After oral administration in mice, IBC inhibited the growth of subcutaneous HL-60 xenograft tumor without obvious toxicity [16].

Microbial transformation has been used as an effective means for structural modification of natural products at non-activated positions. It has advantages over conventional chemical synthesis largely due to its simpler operation, higher selectivity, and milder conditions [17]. In some cases, biological activities may have been enhanced for the transformed metabolites $[18,19]$. Previous studies on the microbial transformation of natural bioactive chalcones identified diverse metabolites with promising activities [20-22]. The aim of the study was to apply microbial transformation of three major bioactive prenylchalcones (1-3) in order to identify new derivatives and evaluate their biological activities to understand their structure-activity relationship.

\section{Materials and Methods}

\subsection{Materials and Reagents}

The herbal material Angelica keiskei was obtained in September 2020 and identified by the herb company Damaon (Yeongcheon, Gyeongsangbuk-do, Korea). Voucher specimen (AK2009) has been deposited at the Herbarium of the College of Pharmacy, Chonnam National University (Gwangju, Korea).

The microbial media including malt extract, peptone, D-glucose, and potato dextrose were obtained from Becton, Dickinson and Co. (Sparks, MD, USA). Sucrose was obtained from Sigma-Aldrich (St. Louis, MO, USA). Dulbecco's modified Eagle medium (DMEM), penicillin, and streptomycin were purchased from Gibco (Invitrogen, Carlsbad, CA, USA). Fetal bovine serum (FBS) was purchased from Welgene Inc. (Gyeongsan, Gyeongsangbukdo, Korea). Phosphate-buffered saline (PBS) tablets were obtained from Takara Korea Biomedical Inc. (Seoul, Korea). 3-(4,5-Dimethylthiazol-2-yl)-2,5-diphenyltetrazolium bromide (MTT) was obtained from Thermo Fisher Scientific (Waltham, MA, USA). Demethylzeylasteral (DZ) used as a reference standard in the bioassay was purchased from Biopurify Phytochemicals, Ltd. (Chengdu, China). Tyrosinase from mushroom and L-tyrosine were purchased from Sigma-Aldrich (St. Louis, MO, USA) and Daejung Chemicals and Metals Co., Ltd. (Siheung, Gyeonggi-do, Korea), respectively. Kojic acid used as a reference standard in the bioassay was purchased from Tokyo Chemical Industry Co., Ltd. (Tokyo, Japan).

The microbial strains including Cunninghamella elegans var. elegans KCTC 6992, Mortierella ramanniana var. angulispora KCTC 6137, Mucor hiemalis KCTC 26779, Mucor plumbeus KCCM 60265, Rhizopus oryzae KCCM 60556 were purchased from the Korean Collection for Type Cultures (KCTC, Daejeon, Korea) or Korean Culture Center of Microorganisms (KCCM, Seoul, Korea). The human cancer cell lines A375P, HT-29, and MCF-7 were obtained from the Korean Cell Line Bank (Seoul, Korea).

\subsection{Isolation and Identification of Chalcones 1-3 from the Aerial Parts of A. keiskei}

The air-dried herbal material $(2.0 \mathrm{~kg})$ was powdered and extracted by soaking in $95 \%$ ethanol $(10 \mathrm{~L} \times 3)$. After concentration of the filtrate, the residue $(432 \mathrm{~g})$ was suspended in water and sequentially partitioned with dichloromethane $\left(\mathrm{CH}_{2} \mathrm{Cl}_{2}\right)$ and ethyl acetate (EtOAc). The crude $\mathrm{CH}_{2} \mathrm{Cl}_{2}$ residue $(59.0 \mathrm{~g}$ ) was subsequently separated by silica gel column chromatography using a gradient of $n$-hexane/EtOAc (30:1-1:1) and $\mathrm{CH}_{2} \mathrm{Cl}_{2} /$ methanol (10:1-0:1) to yield eleven fractions (Fr. A-K). Fr. D (3.76 g) was further subjected to a Sephadex LH-20 column chromatography using methanol to yield five subfractions D1-D5. Subfr. D5 was separated using high performance liquid chromatography (HPLC) to provide substrates $1(50 \mathrm{mg}), 2(95 \mathrm{mg})$, and $3(110 \mathrm{mg})$. The structures of 1-3 were established as isobavachalcone (1) [23], 4-hydroxyderricin (2) [24] and xanthoangelol (3) [25] by ${ }^{1} \mathrm{H}$ - and ${ }^{13} \mathrm{C}$-nuclear magnetic resonance (NMR) spectral analysis (see Supplementary Materials Figures S2-S7). 


\subsection{Preparation and Analysis of Screening Samples for Microbial Transformation}

Fermentation experiments were carried out in two kinds of media. The malt medium consisting of peptone $(1 \mathrm{~g})$, D-glucose $(20 \mathrm{~g})$, and malt extract $(20 \mathrm{~g})$ was prepared in $1 \mathrm{~L}$ of distilled water for the incubation of $M$. hiemalis. The potato sucrose medium consisting of sucrose $(20 \mathrm{~g})$ and potato dextrose $(24 \mathrm{~g})$ was prepared in $1 \mathrm{~L}$ of distilled water for the culture of C. elegans var. elegans, M. ramanniana var. angulispora, M. plumbeus, or $R$. oryzae.

Initial fermentations were performed in $50 \mathrm{~mL}$ media. A two-stage fermentation method was employed in all experiments [26]. After inoculation and continued incubation for $24 \mathrm{~h}$, the solution of each substrate (1-3) in ethanol (20 mg/mL) was distributed to each flask. The concentration of each substrate in the media was $0.02 \mathrm{mg} / \mathrm{mL}$. Incubation was further continued for 4-6 days. The two parallel controls were conducted under the same conditions, i.e., substrate controls (substrate in microorganism-free culture media) and culture controls (microorganisms in substrate-free culture media). Substratecontaining microbial media were sampled by withdrawing $5 \mathrm{~mL}$ of entire media at every two days after addition of substrate. They were extracted with equal volumes of EtOAc. The organic layers were concentrated and spotted on thin layer chromatography (TLC) plates, and developed with chloroform/methanol (6:1). After spraying anisaldehydesulfuric acid reagent, the TLC plates were heated over $100{ }^{\circ} \mathrm{C}$ for detection of potential metabolites (Scheme 1).

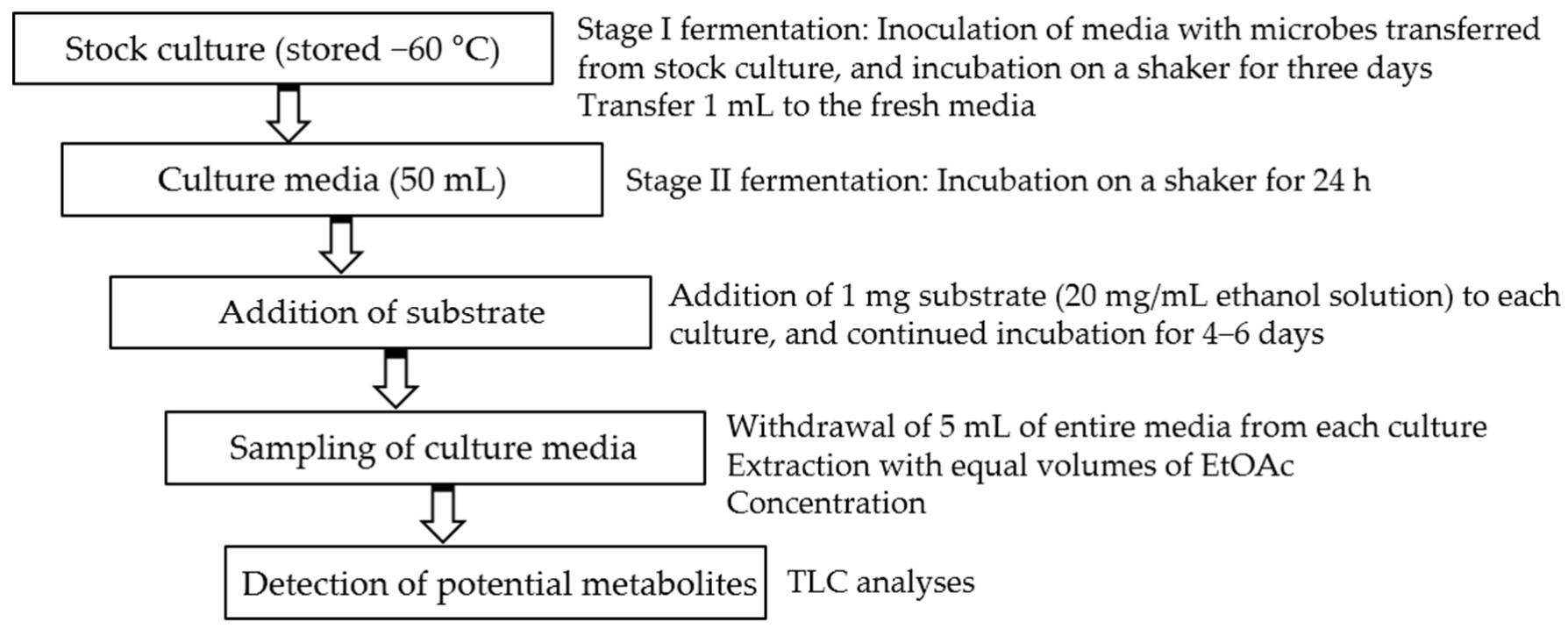

Scheme 1. Two-stage fermentation method for screening.

On the basis of TLC analyses, the microbes M. plumbeus KCCM 60556 and M. hiemalis KCTC 26779 were selected for scale-up fermentations of substrates $\mathbf{1}$ and $\mathbf{2}$, respectively, as they showed higher transformational efficiency, while the microbes M. hiemalis KCTC 26779 and Mortierella ramanniana var. angulispora KCTC 6137 were selected for scale-up fermentations of 3, as they showed potential capability of transforming 3 (See Supplementary Materials Figure S1).

\subsection{Preparation and Isolation of Scale-Up Samples to Obtain Metabolites 4-11}

Scale-up fermentation of each substrate (1-3) was conducted following the aforementioned procedures in $150 \mathrm{~mL}$ of pre-cultured media. The scale-up fermentation culture of each substrate (1-3) was extracted thrice with equal volume of EtOAc. The combined EtOAc extract was evaporated in vacuo to give a residue.

The organic residue of $\mathbf{1}$ cultured with $R$. oryzae was separated on HPLC eluted with $53 \%$ to $84 \%$ methanol to yield metabolites $4\left(t_{R}=30.4 \mathrm{~min}, 2.8 \mathrm{mg}\right)$ and $6\left(t_{R}=34.9 \mathrm{~min}\right.$, $6.5 \mathrm{mg}$ ) together with fractions $\mathrm{RO} 1\left(\mathrm{t}_{\mathrm{R}}=34.1 \mathrm{~min}\right)$ and $\mathrm{RO} 2\left(\mathrm{t}_{\mathrm{R}}=36.8 \mathrm{~min}\right)$ at $2.0 \mathrm{~mL} / \mathrm{min}$. Metabolite $5\left(t_{R}=32.0 \mathrm{~min}, 3.7 \mathrm{mg}\right)$ was obtained by a further purification of fr. RO1 on 
HPLC with 55\% to $72 \%$ methanol. Metabolite $7\left(\mathrm{t}_{\mathrm{R}}=36.8 \mathrm{~min}, 3.2 \mathrm{mg}\right)$ was obtained by a further purification of fr. RO2 on HPLC with a gradient of $53 \%$ to $85 \%$ methanol.

The organic residue of 2 cultured with $M$. hiemalis was separated on HPLC with $58 \%$ to $85 \%$ methanol to furnish $8\left(t_{R}=16.6 \mathrm{~min}, 1.8 \mathrm{mg}\right.$ ) and $9\left(t_{R}=26.4 \mathrm{~min}, 2.2 \mathrm{mg}\right)$ at $2.0 \mathrm{~mL} / \mathrm{min}$.

The organic residue of 3 cultured with $M$. hiemalis was separated on HPLC with $58 \%$ to $97 \%$ methanol to yield metabolite $10\left(3.5 \mathrm{mg}, \mathrm{t}_{\mathrm{R}}=32.8 \mathrm{~min}\right)$ at $2.0 \mathrm{~mL} / \mathrm{min}$.

The organic residue of 3 cultured with Mortierella ramanniana var. angulispora was separated on HPLC with $58 \%$ to $78 \%$ methanol to provide fraction MR1 ( $\left.t_{R}=32.8 \mathrm{~min}\right)$. Metabolites $11\left(2.4 \mathrm{mg}, \mathrm{t}_{\mathrm{R}}=14.8 \mathrm{~min}\right)$ and $12\left(2.2 \mathrm{mg}, \mathrm{t}_{\mathrm{R}}=17.8 \mathrm{~min}\right)$ were yielded by a further purification of fr. MR1 on HPLC with n-hexane: anhydrous EtOH (85: 15, v/v) at $1.0 \mathrm{~mL} / \mathrm{min}$.

\subsection{Structural Characterization of New Metabolites 4, 5, 7, and 10}

2.5.1. 3'-(3-Hydroxy-3-methylbutyl)-4'-O- $\beta$-D-glucopyranosyl-4,2'-dihydroxychalcone (4)

Yellow solid; $[\alpha]_{\mathrm{D}}^{20}-25.2$ (c 0.10, MeOH); UV (MeOH) $\lambda_{\max }: 371 \mathrm{~nm}$; IR $v_{\max }: 3333$, 2855, 1632, 1233, $990 \mathrm{~cm}^{-1}$; HRESIMS m/z: $527.1892[\mathrm{M}+\mathrm{Na}]^{+}$(calcd. for $\mathrm{C}_{26} \mathrm{H}_{32} \mathrm{O}_{10} \mathrm{Na}$, 527.1893); ${ }^{1} \mathrm{H}$ - and ${ }^{13} \mathrm{C}-\mathrm{NMR}$ spectral data: see Table 1.

Table 1. ${ }^{1} \mathrm{H}$ - and ${ }^{13} \mathrm{C}-\mathrm{NMR}$ data for $4,5,7$, and 10.

\begin{tabular}{|c|c|c|c|c|c|c|c|c|}
\hline \multirow[b]{2}{*}{$\mathrm{C} / \mathrm{H}$} & \multicolumn{2}{|c|}{$4^{a}$} & \multicolumn{2}{|c|}{$5^{a}$} & \multicolumn{2}{|c|}{$7^{a}$} & \multicolumn{2}{|c|}{$10^{b}$} \\
\hline & $\delta_{\mathrm{H}}(\mathrm{J} / \mathrm{Hz})$ & $\delta_{C}$ & $\delta_{\mathrm{H}}(J / \mathrm{Hz})$ & $\delta_{C}$ & $\delta_{\mathrm{H}}(\mathrm{J} / \mathrm{Hz})$ & $\delta_{C}$ & $\delta_{H}(J / H z)$ & $\delta_{C}$ \\
\hline$\alpha$ & $7.66 \mathrm{~d}(15.5)$ & 118.4 & $7.67 \mathrm{~d}(15.2)$ & 118.4 & $7.65 \mathrm{~d}(15.3)$ & 118.4 & $7.80 \mathrm{~d}(15.3)$ & 117.1 \\
\hline$\beta$ & $7.82 \mathrm{~d}(15.5)$ & 146.4 & $7.84 \mathrm{~d}(15.2)$ & 146.4 & $7.83 \mathrm{~d}(15.3)$ & 146.4 & $7.84 \mathrm{~d}(15.3)$ & 145.0 \\
\hline $\mathrm{C}=\mathrm{O}$ & & 194.5 & & 194.5 & & 194.5 & & 192.5 \\
\hline 1 & & 127.9 & & 127.9 & & 127.9 & & 125.6 \\
\hline 2,6 & $7.64 \mathrm{~d}(8.6)$ & 132.1 & $7.66 \mathrm{~d}(8.6)$ & 132.1 & $7.64 \mathrm{~d}(8.6)$ & 132.1 & 7.79 d (8.5) & 131.5 \\
\hline 3,5 & $6.85 \mathrm{~d}(8.6)$ & 117.1 & $6.87 \mathrm{~d}(8.6)$ & 117.1 & $6.85 \mathrm{~d}(8.6)$ & 117.1 & $6.85 \mathrm{~d}(8.5)$ & 115.9 \\
\hline 4 & & 161.9 & & 161.9 & & 161.9 & & 160.6 \\
\hline $1^{\prime}$ & & 116.6 & & 116.6 & & 116.6 & & 114.5 \\
\hline $2^{\prime}$ & & 164.1 & & 164.2 & & 164.2 & & 162.4 \\
\hline $3^{\prime}$ & & 120.8 & & 120.5 & & 120.7 & & 117.1 \\
\hline $4^{\prime}$ & & 162.6 & & 162.6 & & 162.6 & & 161.0 \\
\hline $5^{\prime}$ & $6.80 \mathrm{~d}(9.0)$ & 107.2 & $6.82 \mathrm{~d}(9.1)$ & 107.1 & $6.80 \mathrm{~d}(9.0)$ & 107.1 & $6.74 \mathrm{~d}(9.2)$ & 105.9 \\
\hline $6^{\prime}$ & $7.98 \mathrm{~d}(9.0)$ & 130.6 & $8.00 \mathrm{~d}(9.1)$ & 130.6 & $7.98 \mathrm{~d}(9.0)$ & 130.6 & $8.21 \mathrm{~d}(9.2)$ & 130.6 \\
\hline $1^{\prime \prime}$ & $2.81 \mathrm{~m}$ & 18.6 & $2.78 \mathrm{~m}$ & 18.2 & $2.77 \mathrm{~m}$ & 18.3 & $\begin{array}{c}3.44 \mathrm{~m}, 3.24 \\
\mathrm{~m}\end{array}$ & 21.4 \\
\hline $2^{\prime \prime}$ & $1.66 \mathrm{~m}$ & 43.2 & $1.71 \mathrm{~m}$ & 39.2 & $1.69 \mathrm{~m}$ & 39.7 & $5.22 \mathrm{~m}$ & 121.9 \\
\hline $3^{\prime \prime}$ & & 72.0 & & 76.9 & & 76.7 & & 134.3 \\
\hline $4^{\prime \prime}$ & $1.28 \mathrm{~s}$ & 28.7 & $1.27 \mathrm{~s}$ & 25.1 & $1.26 \mathrm{~s}$ & 25.7 & $1.90 \mathrm{~m}$ & 39.3 \\
\hline $5^{\prime \prime}$ & $1.26 \mathrm{~s}$ & 29.8 & $1.25 \mathrm{~s}$ & 25.8 & $1.24 \mathrm{~s}$ & 26.6 & $1.99 \mathrm{~m}$ & 26.2 \\
\hline $6^{\prime \prime}$ & & & $3.31 \mathrm{~s}$ & 49.8 & $3.55 \mathrm{q}(7.0)$ & 58.0 & $5.04 \mathrm{t}(7.0)$ & 124.2 \\
\hline $7^{\prime \prime}$ & & & & & $1.21 \mathrm{t}(7.0)$ & 16.5 & & 129.9 \\
\hline $8^{\prime \prime}$ & & & & & & & $1.59 \mathrm{~s}$ & 25.5 \\
\hline $9^{\prime \prime}$ & & & & & & & $1.53 \mathrm{~s}$ & 17.5 \\
\hline $10^{\prime \prime}$ & & & & & & & $1.75 \mathrm{~s}$ & 16.0 \\
\hline $1^{\prime \prime \prime}$ & $5.01 \mathrm{~d}(7.5)$ & 102.0 & $5.06 \mathrm{~d}(7.3)$ & 101.9 & $5.04 \mathrm{~d}(7.3)$ & 102.0 & $5.00 \mathrm{~d}(7.3)$ & 100.1 \\
\hline $2^{\prime \prime \prime}$ & $3.53 \mathrm{~m}$ & 75.0 & $3.52 \mathrm{~m}$ & 75.1 & $3.51 \mathrm{~m}$ & 75.1 & $3.32 \mathrm{~m}$ & 73.4 \\
\hline $3^{\prime \prime \prime}$ & $3.49 \mathrm{~m}$ & 78.5 & $3.51 \mathrm{~m}$ & 78.5 & $3.49 \mathrm{~m}$ & 78.5 & $3.39 \mathrm{~m}$ & 77.3 \\
\hline $4^{\prime \prime \prime}$ & $3.41 \mathrm{~m}$ & 71.4 & $3.42 \mathrm{~m}$ & 78.4 & $3.41 \mathrm{~m}$ & 71.4 & $3.18 \mathrm{~m}$ & 69.8 \\
\hline $5^{\prime \prime \prime}$ & $3.49 \mathrm{~m}$ & 78.2 & $3.50 \mathrm{~m}$ & 71.4 & $3.49 \mathrm{~m}$ & 78.3 & $3.32 \mathrm{~m}$ & 76.8 \\
\hline & $3.92 \mathrm{dd}$ & & $3.93 \mathrm{dd}$ & & $3.92 \mathrm{dd}$ & & & \\
\hline $6^{\prime \prime \prime}$ & $(12.1,2.0)$ & & $(12.1,2.1)$ & & $(12.3,2.1)$ & & $3.71 \mathrm{~m}$ & \\
\hline $6^{\prime \prime \prime}$ & $3.72 \mathrm{dd}$ & 62.6 & $3.74 \mathrm{dd}$ & 62.7 & $3.72 \mathrm{dd}$ & 62.7 & $3.46 \mathrm{~m}$ & 60.7 \\
\hline & $(12.1,5.0)$ & & $(12.1,5.9)$ & & $(12.3,5.3)$ & & & \\
\hline
\end{tabular}

Assignments were achieved on the basis of 1D and 2D NMR data. The values of $J$ are presented in parentheses.

a Data were acquired in methanol- $d_{4} \cdot{ }^{\mathrm{b}}$ Data were acquired in DMSO- $d_{6}$. 
2.5.2. 3'-(3-O-Methyl-3-methylbutyl)-4'-O- $\beta$-D-glucopyranosyl-4,2' -dihydroxychalcone (5)

Yellow solid; $[\alpha]_{\mathrm{D}}^{20}-26.9$ (c 0.10, MeOH); UV (MeOH) $\lambda_{\max }: 365 \mathrm{~nm}$; IR $v_{\max }: 3330$, 2927, 1780, 1632, 1284, 1105, $1074 \mathrm{~cm}^{-1}$; HRESIMS m/z: 541.2049 [M+Na] $^{+}$(calcd. for $\left.\mathrm{C}_{27} \mathrm{H}_{34} \mathrm{O}_{10} \mathrm{Na}, 541.2050\right) ;{ }^{1} \mathrm{H}$ - and ${ }^{13} \mathrm{C}-\mathrm{NMR}$ spectral data: see Table 1.

2.5.3. 3'-(3-O-Ethyl-3-methylbutyl)-4'-O- $\beta$-D-glucopyranosyl-4,2'-dihydroxychalcone (7)

Yellow solid; $[\alpha]_{\mathrm{D}}^{20}-46.5$ (c 0.10, MeOH); UV (MeOH) $\lambda_{\max }: 363 \mathrm{~nm}$; IR $v_{\max }: 3319,2919$, $1604,1285,1105,835 \mathrm{~cm}^{-1}$; HRESIMS m/z: $555.2208[\mathrm{M}+\mathrm{Na}]^{+}$(calcd. for $\mathrm{C}_{28} \mathrm{H}_{36} \mathrm{O}_{10} \mathrm{Na}$, 555.2206); ${ }^{1} \mathrm{H}$ - and ${ }^{13} \mathrm{C}-\mathrm{NMR}$ spectral data: see Table 1.

\subsubsection{4'-O- $\beta$-D-Glucopyranosyl xanthoangelol (10)}

Yellow solid; $[\alpha]_{\mathrm{D}}^{20}-28.0$ (c 0.10, MeOH); UV (MeOH) $\lambda_{\max }: 365 \mathrm{~nm}$; IR $v_{\max }: 3342,2926$, $1713,1631,1233,1076 \mathrm{~cm}^{-1}$; HRESIMS m/z: $577.2414[\mathrm{M}+\mathrm{Na}]^{+}$(calcd. for $\mathrm{C}_{31} \mathrm{H}_{38} \mathrm{O}_{9} \mathrm{Na}$, 577.2414); ${ }^{1} \mathrm{H}$ - and ${ }^{13} \mathrm{C}-\mathrm{NMR}$ spectral data: see Table 1.

\subsection{Acid Hydrolysis of 4, 5, 7, and $\mathbf{1 0}$}

Each solution of compounds 4, 5, 7, and 10 (each $0.8 \mathrm{mg}$ ) in $2 \mathrm{~mL} 2 \mathrm{~N} \mathrm{HCl}$ was heated at $85^{\circ} \mathrm{C}$ for $3 \mathrm{~h}$. After cooling and neutralization, the reaction mixture was extracted with EtOAc. The water layer was concentrated and confirmed by TLC in comparison with authentic D-glucose as a standard. The organic layer containing the aglycone of $\mathbf{1 0}$ was determined as the corresponding substrate 3 by comparing their retention time on HPLC.

\subsection{Cytotoxic Activity Evaluation}

The cytotoxicity assays were conducted according to the MTT method as previously described [27] using human melanoma A375P, human colorectal HT-29, and human breast cancer MCF-7 cell lines. Briefly, cells were incubated in 96-well plates at an approximate density of $5.0 \times 10^{3}$ cells / well with $100 \mu \mathrm{L}$ DMEM medium supplemented with 5\% FBS, penicillin $(100 \mathrm{U} / \mathrm{mL})$ and streptomycin $(100 \mu \mathrm{g} / \mathrm{mL})$ at $37^{\circ} \mathrm{C}$ with $5 \% \mathrm{CO}_{2}$ for $24 \mathrm{~h}$. Then, cells were fed with different concentrations of the test compounds (1-12) for another $48 \mathrm{~h}$. After gently removing the culture media, $100 \mu \mathrm{L}$ of MTT solution $(0.5 \mathrm{mg} / \mathrm{mL})$ was applied for staining the cells. Finally, absorbance of each plate was observed at $490 \mathrm{~nm}$ by the microplate reader after removal of MTT solution and addition of $100 \mu \mathrm{L}$ dimethyl sulfoxide.

\subsection{Tyrosinase Inhibitory Activity}

L-Tyrosine was used as a substrate to evaluate the tyrosinase inhibition of 1-12 following the previously developed method $[28,29]$ with some modifications. The tyrosinase inhibition assay was performed using $0.1 \mathrm{M}$ phosphate buffer ( $\mathrm{pH}$ 6.5), $2 \mathrm{mM}$ L-tyrosine, and test compound solution with different concentrations ranging from $10 \mu \mathrm{M}$ to $100 \mu \mathrm{M}$. The mixture was prepared 5 min before treatment with the enzyme solution $(150 \mathrm{U} / \mathrm{mL})$. In the experiments, the reaction mixture without tyrosinase was used as a blank, and the reaction mixture without sample solution was used as a negative control. Kojic acid was used as a positive control. After incubation for $30 \mathrm{~min}$ at $37^{\circ} \mathrm{C}$, absorbance of the reaction mixture was recorded at $490 \mathrm{~nm}$ to evaluate the amount of dopachrome produced in the process. The extent of tyrosinase inhibition by compounds 1-12 is displayed as the half maximal inhibitory concentration $\left(\mathrm{IC}_{50}\right)$ in Table 2. 
Table 2. Cytotoxic and tyrosinase inhibitory activities of 1-12 ${ }^{a}$.

\begin{tabular}{ccccc}
\hline \multirow{2}{*}{ Compound } & \multicolumn{4}{c}{ IC $_{\mathbf{5 0}} \pm \mathbf{S D}(\boldsymbol{\mu M})$} \\
\cline { 2 - 5 } & $\mathbf{A 3 7 5 P}$ & HT-29 & MCF-7 & Tyrosinase \\
\hline $\mathbf{1}$ & $9.78 \pm 1.06$ & $26.33 \pm 2.42$ & $24.02 \pm 0.36$ & $>100$ \\
$\mathbf{2}$ & $25.34 \pm 0.66$ & $37.30 \pm 4.86$ & $29.71 \pm 2.78$ & $>100$ \\
$\mathbf{3}$ & $13.00 \pm 1.28$ & $24.35 \pm 1.27$ & $21.92 \pm 2.30$ & $>100$ \\
$\mathbf{4}$ & $>80$ & $>80$ & $>80$ & $78.47 \pm 3.13$ \\
$\mathbf{5}$ & $77.96 \pm 3.44$ & $>80$ & $>80$ & $28.68 \pm 1.24$ \\
$\mathbf{6}$ & $>80$ & $>80$ & $>80$ & $43.12 \pm 6.74$ \\
$\mathbf{7}$ & $>80$ & $>80$ & $>80$ & $33.32 \pm 1.16$ \\
$\mathbf{8}$ & $29.65 \pm 2.09$ & $54.36 \pm 1.03$ & $32.44 \pm 0.55$ & $>100$ \\
$\mathbf{9}$ & $21.18 \pm 0.20$ & $58.55 \pm 4.19$ & $28.18 \pm 1.34$ & $52.65 \pm 2.85$ \\
$\mathbf{1 0}$ & $29.03 \pm 2.77$ & $>80$ & $>80$ & $71.71 \pm 9.22$ \\
$\mathbf{1 1}$ & $69.77 \pm 3.88$ & $>80$ & $>80$ & $>100$ \\
$\mathbf{1 2}$ & $20.56 \pm 2.17$ & $>80$ & $59.01 \pm 2.41$ & $>100$ \\
$\mathbf{D Z}$ & $2.52 \pm 0.23$ & $8.68 \pm 0.90$ & $2.87 \pm 0.38$ & \\
Kojic acid & & & & $77.74 \pm 2.55$ \\
\hline
\end{tabular}

${ }^{a}$ Results are expressed as the mean values of three experiments \pm SD.

\section{Results}

Microbial transformation of three bioactive prenylchalcones 1-3 is reported herein. Fermentation of 1 with $R$. oryzae KCCM 60,556 furnished three new (4, 5, and 7) and one known (6) metabolites. Fermentation of 2 with $M$. hiemalis KCTC 26,779 furnished two known (8 and 9) metabolites. Fermentation of 3 with M. hiemalis KCTC 26,779 furnished one new (10) metabolite, while that with M. ramanniana var. angulispora KCTC 6137 resulted in the production of two known (11 and 12) metabolites (Figure 1) (Figures S8-S41).
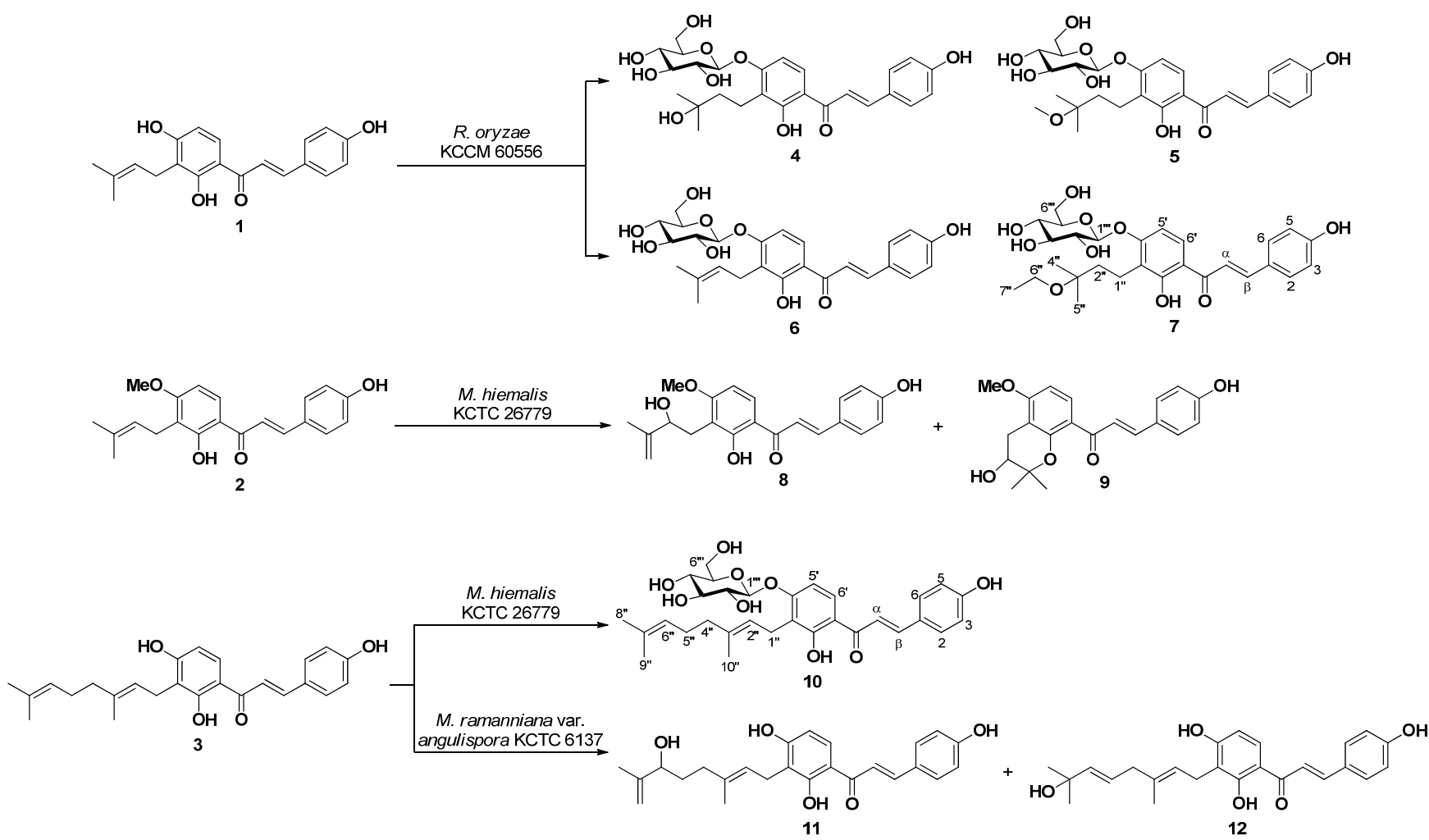

Figure 1. Compounds 4-12 obtained by microbial transformation of 1-3.

Compound 4 was obtained as a yellow solid. High resolution electrospray ionization mass spectrometry (HRESIMS) measurements on 4 revealed a molecular formula of $\mathrm{C}_{26} \mathrm{H}_{32} \mathrm{O}_{10}$ corresponding to 11 unsaturation by the occurrence of its HRESIMS ion peak at 
$m / z 527.1892[\mathrm{M}+\mathrm{Na}]^{+}$(calcd. for $\mathrm{C}_{26} \mathrm{H}_{32} \mathrm{O}_{10} \mathrm{Na}$, 527.1893). The typical ultraviolet (UV) absorption at $371 \mathrm{~nm}$ indicated the appearance of a chalcone scaffold $[4,30]$. Inspection of its spectroscopic data revealed the presence of characteristic resonances for a chalcone skeleton with a 3-hydroxy-3-methylbutyl group and a sugar moiety. The ${ }^{1} \mathrm{H}-\mathrm{NMR}$ data presented signals assignable to two ortho-coupled aromatic protons at $\delta_{\mathrm{H}} 7.98(1 \mathrm{H}, \mathrm{d}$, $J=9.0)$ and $6.80(1 \mathrm{H}, \mathrm{d}, J=9.0 \mathrm{~Hz})$ and four aromatic protons at $\delta_{\mathrm{H}} 7.64(2 \mathrm{H}, \mathrm{d}, J=8.6 \mathrm{~Hz})$ and $6.85(2 \mathrm{H}, \mathrm{d}, J=8.6 \mathrm{~Hz})$. Meanwhile, an olefin moiety was identified by the observation of signals at $\delta_{\mathrm{H}} 7.82(1 \mathrm{H}, \mathrm{d}, J=15.5)$ and $7.66(1 \mathrm{H}, \mathrm{d}, J=15.5)$. These typical resonances suggested the existence of a $4,2^{\prime}, 3^{\prime}, 4^{\prime}$-tetrasubstituted chalcone. The two multiplets at $\delta_{\mathrm{H}}$ $2.81(2 \mathrm{H})$ and $1.66(2 \mathrm{H})$ and two singlets at $\delta_{\mathrm{H}} 1.28(3 \mathrm{H})$ and $1.26(3 \mathrm{H})$ were attributed to the 3-hydroxy-3-methylbutyl group, whereas the anomeric proton at $\delta_{\mathrm{H}} 5.01(1 \mathrm{H}, \mathrm{d}$, $J=7.5 \mathrm{~Hz}$ ), together with the characteristic carbon signals at $\delta_{C} 102.0,78.5,78.2,75.0,71.4$, and 62.6 demonstrated that the sugar moiety was a $\beta$-D-glucopyranose [31,32]. Significant heteronuclear multiple bond coherence (HMBC) correlation between the anomeric proton signal at $\delta_{\mathrm{H}} 5.00\left(\mathrm{H}-1^{\prime \prime \prime}\right)$ and $\delta_{\mathrm{C}} 162.6\left(\mathrm{C}-4^{\prime}\right)$ indicated that the $\beta$-D-glucose was attached to the $\mathrm{C}-4^{\prime}$ position, while the 3-hydroxy-3-methylbutyl group was located at $\mathrm{C}-3^{\prime}$ on the basis of the HMBC correlations between $\delta_{\mathrm{H}} 2.81\left(\mathrm{H}-1^{\prime \prime}\right) / 1.66\left(\mathrm{H}-2^{\prime \prime}\right)$ and $\delta_{\mathrm{c}} 120.8\left(\mathrm{C}-3^{\prime}\right)$. Furthermore, acid hydrolysis of 4 produced D-glucose which was confirmed through direct comparison with the standard on TLC. Thus, the structure of 4 was characterized as 3'-(3-hydroxy-3-methylbutyl)-4'-O- $\beta$-D-glucopyranosyl-4,2'-dihydroxychalcone.

Compound 5 was assigned the composition $\mathrm{C}_{27} \mathrm{H}_{34} \mathrm{O}_{10}$ from its HRESIMS at $\mathrm{m} / z$ $541.2049[\mathrm{M}+\mathrm{Na}]^{+}$(calcd. for $\left.\mathrm{C}_{27} \mathrm{H}_{34} \mathrm{O}_{10} \mathrm{Na}, 541.2050\right)$. The ${ }^{1} \mathrm{H}$ - and ${ }^{13} \mathrm{C}-\mathrm{NMR}$ spectra of 5 were quite similar to those of 4 , except for the resonances of a methoxy group $\left(\delta_{\mathrm{H}} 3.31 / \delta_{\mathrm{C}}\right.$ $49.8)$ in 5 . The attachment of the methoxy group was determined to be at $\mathrm{C}-3^{\prime \prime}$ according to the HMBC correlations from the methoxy protons $\mathrm{H}-6^{\prime \prime}\left(\delta_{\mathrm{H}} 3.31\right)$ to $\mathrm{C}-3^{\prime \prime}\left(\delta_{\mathrm{C}} 76.9\right)$ and $\mathrm{C}-2^{\prime \prime}\left(\delta_{\mathrm{C}} 39.2\right)$. Thus, the structure of 5 was determined as $3^{\prime}-(3-O-m e t h y l-3-m e t h y l b u t y l)-$ $4^{\prime}-O-\beta$-D-glucopyranosyl-4,2'-dihydroxychalcone.

The molecular formula of compound 7 was determined as $\mathrm{C}_{28} \mathrm{H}_{36} \mathrm{O}_{10}$ using HRESIMS on the basis of a molecular ion at $m / z 555.2208[\mathrm{M}+\mathrm{Na}]^{+}$(calcd. for $\mathrm{C}_{28} \mathrm{H}_{36} \mathrm{O}_{10} \mathrm{Na}, 555.2206$ ), which corresponded to 11 degrees of unsaturation. The NMR data of 7 were almost identical to those observed for 4 except for the appearance of one $O$-methylene $\left(\delta_{\mathrm{H}} 3.55,2 \mathrm{H}, \mathrm{q}\right.$, $\left.J=7.0 \mathrm{~Hz} / \delta_{\mathrm{C}} 58.0\right)$ and one methyl $\left(\delta_{\mathrm{H}} 1.21,3 \mathrm{H}, \mathrm{t}, J=7.0 \mathrm{~Hz} / \delta_{\mathrm{C}} 16.5\right)$ signals corresponding to $\mathrm{H}-6^{\prime \prime}$ and $\mathrm{H}-\mathrm{7}^{\prime \prime}$, readily attributable to an ethyloxy group. Further evidence was obtained from the obvious correlation between proton signals $\mathrm{H}-6^{\prime \prime}$ and $\mathrm{H}-\mathrm{-}^{\prime \prime}$ (Figure 2) in the ${ }^{1} \mathrm{H}-{ }^{1} \mathrm{H}$ homonuclear correlation spectroscopy (COSY) experiment. HMBC correlation between $\mathrm{H}-6^{\prime \prime}$ and $\mathrm{C}-3^{\prime \prime}$ confirmed the location of the ethyloxy group at C-3". Accordingly, the structure of 7 was assigned $3^{\prime}$-(3-O-ethyl-3-methylbutyl)-4'-O- $\beta$-D-glucopyranosyl-4,2'dihydroxychalcone.
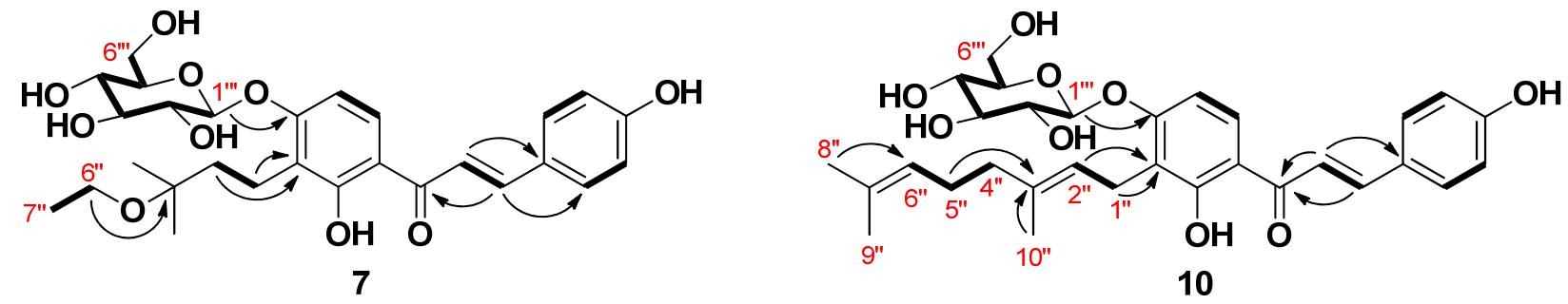

Figure 2. Key COSY $\left({ }^{1} \mathrm{H}_{-}{ }^{1} \mathrm{H}\right)$ and $\mathrm{HMBC}\left({ }^{1} \mathrm{H} \rightarrow{ }^{13} \mathrm{C}\right)$ correlations of compounds $\mathbf{7}$ and $\mathbf{1 0 .}$

Compound 10 was confirmed to have $\mathrm{C}_{31} \mathrm{H}_{38} \mathrm{O}_{9}$ as the elemental composition according to the analysis of its HRESIMS data. The ${ }^{1} \mathrm{H}-\mathrm{NMR}$ spectrum of compound $\mathbf{1 0}$ displayed two sets of aromatic proton resonances at $\delta_{\mathrm{H}} 8.21(1 \mathrm{H}, \mathrm{d}, J=9.2)$ and $6.74(1 \mathrm{H}$, $\mathrm{d}, J=9.2), 7.79(2 \mathrm{H}, \mathrm{d}, J=8.5)$, and $6.85(2 \mathrm{H}, \mathrm{d}, J=8.5)$ together with two olefinic proton resonances at $\delta_{\mathrm{H}} 7.84(1 \mathrm{H}, \mathrm{d}, J=15.3)$ and $7.80(1 \mathrm{H}, \mathrm{d}, J=15.3)$ assignable to the $4,2^{\prime}, 3^{\prime}, 4^{\prime}$ tetrasubstituted chalcone. In addition, proton resonance signals for a geranyl group and 
a sugar moiety were identified in the up-field region. Analysis of the COSY spectrum together with the heteronuclear single quantum coherence (HSQC) and HMBC spectra allowed the establishment of the structure as $4,2^{\prime}, 4^{\prime}$-trihydroxychalcone substituted with a geranyl group and a sugar moiety in $\mathbf{1 0}$ (Figure 2). The ${ }^{13} \mathrm{C}-\mathrm{NMR}$ data showed six signals at $\delta_{C} 100.1,77.3,76.8,73.4,69.8$, and 60.7 , which are characteristic of a glucose moiety [31]. The anomeric proton signal at $\delta_{\mathrm{H}} 5.00(1 \mathrm{H}, \mathrm{d}, J=7.3 \mathrm{~Hz})$ indicated a $\beta$-configuration of the glucosidic bond. The connectivity of the glucose moiety in $\mathbf{1 0}$ was confirmed to be at C-4' through an ether linkage by the HMBC correlation from the anomeric proton signal $\mathrm{H}-1^{\prime \prime \prime}$ to $C-4^{\prime}$. Presence of the glucose moiety and its aglycone after acid hydrolysis was further confirmed by comparison of their TLC and HPLC identification pattern with those of the authentic samples. Linkage of the geranyl group was deduced to be at C-3' position by the observation of $\mathrm{HMBC}$ correlations from $\mathrm{H}-1^{\prime \prime} / \mathrm{H}-2^{\prime \prime}$ to $\mathrm{C}-3^{\prime}$. Hence, $\mathbf{1 0}$ was assigned $4^{\prime}$-O- $\beta$-D-glucopyranosyl xanthoangelol.

Structures of the five known metabolites were identified as $3^{\prime}$-(3-methyl-2-butenyl)-4' O- $\beta$-D-glucopyranosyl-4,2'-dihydroxychalcone (6) [33], xanthoangelols $H(8)$ [34,35] and $\mathrm{D}$ (9) [36], xanthokeismin A (11) [5], and xanthoangelol B (12) [25] by comparing ${ }^{1} \mathrm{H}$ - and ${ }^{13} \mathrm{C}-\mathrm{NMR}$ data with those reported in the literature.

In this study, cytotoxicity of compounds 1-12 was determined by MTT assays against A375P, HT-29, and MCF-7 human cancer cells. As shown in Table 2, compounds 1 and 3 showed most potent cytotoxicity against A375P, HT-29, and MCF-7. Compound 2 exhibited moderate cytotoxic activity toward human cancer cell lines tested. However, all the metabolites 4-12 exhibited lower cytotoxicity compared with their corresponding substrates 1, 2, and 3. It appears that the $C$-prenyl or $C$-geranyl side chain is essential for cytotoxic activity. Meanwhile, glucosylation or methylation at $4^{\prime}-\mathrm{OH}$ decreased the cytotoxicity.

The capability of 1-12 to inhibit tyrosinase was determined using L-tyrosine as a substrate. The most potent compounds were 5 and 7 , which displayed respectively 2.5- and 2-fold stronger inhibition compared with the positive control. Compound 4 showed moderate activity comparable to kojic acid. It was suggested that methyl or ethyl moiety introduced at the 3-O position of 3-hydroxy-3-methylbutyl group could improve the inhibitory activity against mushroom tyrosinase. The anti-tyrosinase potencies were enhanced in chalcone $4^{\prime}$-O-glucosides (6 and 10) compared with their corresponding aglycones ( $\mathbf{1}$ and $3)$. This allowed us to postulate that the introduction of $4^{\prime}$-O-glucopyranosyl group led to the improvement in the tyrosinase inhibitory capacity.

\section{Discussion}

In this work, three bioactive prenylchalcones, isobavachalcone (IBC, 1), 4-hydroxyderricin $(\mathrm{HD}, 2)$, and xanthoangelol (XT, 3), were isolated from A. keiskei and subjected to microbial transformation. The reaction types consisted of hydroxylation, methylation, ethylation, rearrangement, and glucosylation. These highly specific reactions are difficult to achieve by synthetic methods, especially under mild conditions. Therefore, microbial transformation is a useful way in structural diversification of chalcones to discover valuable derivatives. In addition, microbial transformation permits the possibility of understanding the metabolic pathway [37]. It is particularly noteworthy that microbial transformation of HD (2) with the microbe $M$. hiemalis produced two metabolites xanthoangelols $\mathrm{H}(8)$ and D (9), while microbial transformation of XT (3) with the microbe Mortierella ramanniana var. angulispora resulted in the production of two metabolites xanthokeismin A (11) and xanthoangelol $\mathrm{B}$ (12). All the four known metabolites $(8,9,11$, and 12) were previously identified from the herb $A$. keiskei. The information could be beneficial for understanding the metabolic pathways of these compounds in this plant.

Tyrosinase is a metalloenzyme containing two copper atoms and acts as a ratelimiting oxidase involved in the production of melanin [38]. During melanogenesis, tyrosinase is able to act as a hydroxylase to catalyze the conversion of L-tyrosine to L-3,4-dihydroxyphenylalanine (L-DOPA) and subsequently is able to act as an oxidase to catalyze the conversion of L-DOPA to L-dopaquinone, which results in the accumulation 
of melanin and hyperpigmentation [39]. In recent years, it has been demonstrated that various dermatological disorders, such as age spots, melasma freckle, and sites of actinic damage, derive from the accumulation of an exaggerated level of epidermal pigmentation. Tyrosinase has been recognized as a significant target for the treatment of skin disorders related to irregular pigmentation [40]. Thus, the identification of new and potent leads with tyrosinase inhibitory activity has attracted considerable interest in medication and cosmetics. Chalcones represent a diverse class of compounds generally presented in higher plants. Structurally, compounds with the scaffold of 4-hydroxychalcone are considered as potent tyrosinase inhibitors owing to the structural similarity between 4-hydroxychalcone and tyrosine (Figure 3) [41]. In this study, the structure -activity relationship of twelve compounds (1-12) with the scaffold of 4-hydroxychalcone was investigated for its tyrosinase inhibitory activity. The results revealed that the glucosylation of the $\mathrm{OH}$ group at $\mathrm{C}-4^{\prime}$ position is important in the enhancement of the inhibition. Furthermore, the insertion of a methyl (compound 5) or an ethyl group (compound 7) into the 3-hydroxy-3-methylbutyl group at the 3-O position dramatically improved the inhibition. Considering that 5 and 7 showed the most potent tyrosinase inhibition with relatively low cytotoxicity, as shown in Table 2, they can act as potential leads for the development of effective and safe anti-browning and skin-whitening agents.

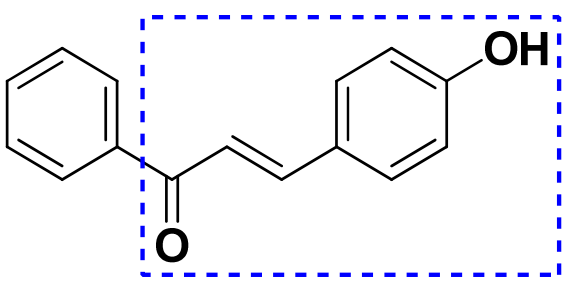

4-Hydroxychalcone

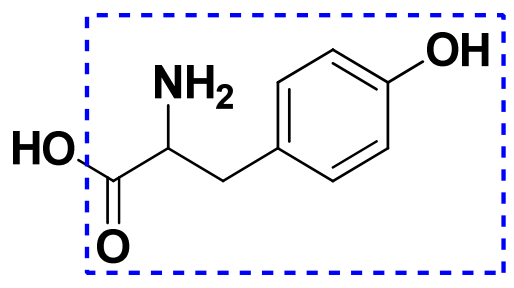

Tyrosine

Figure 3. The structural similarity between 4-hydroxychalcone and tyrosine.

\section{Conclusions}

Microbial transformation of three bioactive prenylchalcones 1-3 isolated from A. keiskei afforded four new $(4,5,7$, and 10) and five known $(6,8,9,11$, and 12) metabolites. The five known metabolites were all previously reported from natural sources. In the evaluation of all compounds for their cytotoxic and tyrosinase inhibitory activities, metabolites $\mathbf{5}$ and $\mathbf{7}$ exhibited the most potent tyrosinase inhibition with relatively low cytotoxicity. The two metabolites 5 and 7 can be considered as new leads for the further design of tyrosinase inhibitors. The present results indicate that microbial transformation can be an efficient and useful tool for the identification of natural product-like compounds as bioactive leads.

Supplementary Materials: The following supporting information can be downloaded at: https: / / www.mdpi.com/article/10.3390/foods11040543/s1, Figure S1: TLC analyses for microbial transformation of 1-3 by selected microbes, Figures S2-S41: 1D, 2D NMR, and HRESIMS spectra of 1-12.

Author Contributions: Conceptualization, I.-S.L.; methodology, Y.X. and I.-S.L.; validation, Y.X.; formal analysis, I.-S.L.; investigation, Y.X. and I.-S.L.; resources, Y.X.; data curation, Y.X.; writingoriginal draft preparation, Y.X.; writing-review and editing, I.-S.L.; visualization, Y.X.; supervision, I.-S.L.; project administration, I.-S.L.; funding acquisition, Y.X. and I.-S.L. All authors have read and agreed to the published version of the manuscript.

Funding: This research was supported by the Basic Science Research Program through the National Research Foundation of Korea (NRF), funded by the Ministry of Education (NRF-2019R1I1A3A01043084 and NRF-2021R1I1A1A01056116).

Institutional Review Board Statement: Not applicable.

Informed Consent Statement: Not applicable. 


\section{Data Availability Statement: Not applicable.}

Acknowledgments: The authors would like to acknowledge the Center for Research Facilities, Chonnam National University, and the Korea Basic Science Institute (KBSI) for their support to operate the NMR, IR, and HRESIMS experiments.

Conflicts of Interest: The authors declare no conflict of interest.

\section{References}

1. Kil, Y.-S.; Pham, S.T.; Seo, E.K.; Jafari, M. Angelica keiskei, an emerging medicinal herb with various bioactive constituents and biological activities. Arch. Pharm. Res. 2017, 40, 655-675. [CrossRef] [PubMed]

2. Zhang, L.; Jiang, Y.; Pang, X.; Hua, P.; Gao, X.; Li, Q.; Li, Z. Simultaneous optimization of ultrasound-assisted extraction for flavonoids and antioxidant activity of Angelica keiskei using response surface methodology (RSM). Molecules 2019, $24,3461$. [CrossRef] [PubMed]

3. Caesar, L.K.; Cech, N.B. A review of the medicinal uses and pharmacology of ashitaba. Planta Med. 2016, 82, 1236-1245. [CrossRef] [PubMed]

4. $\quad$ Akihisa, T.; Tokuda, H.; Hasegawa, D.; Ukiya, M.; Kimura, Y.; Enjo, F.; Suzuki, T.; Nishino, H. Chalcones and other compounds from the exudates of Angelica keiskei and their cancer chemopreventive effects. J. Nat. Prod. 2006, 69, 38-42. [CrossRef] [PubMed]

5. Aoki, N.; Muko, M.; Ohta, E.; Ohta, S. C-geranylated chalcones from the stems of Angelica keiskei with superoxide-scavenging activity. J. Nat. Prod. 2008, 71, 1308-1310. [CrossRef] [PubMed]

6. Inamori, Y.; BABA, K.; Tsujibo, H.; Taniguchi, M.; Nakata, K.; KOZAWA, M. Antibacterial activity of two chalcones, xanthoangelol and 4-hydroxyderricin, isolated from the root of Angelica keiskei KOIDZUMI. Chem. Pharm. Bull. 1991, 39, 1604-1605. [CrossRef]

7. Enoki, T.; Ohnogi, H.; Nagamine, K.; Kudo, Y.; Sugiyama, K.; Tanabe, M.; Kobayashi, E.; Sagawa, H.; Kato, I. Antidiabetic activities of chalcones isolated from a Japanese herb, Angelica keiskei. J. Agric. Food Chem. 2007, 55, 6013-6017. [CrossRef]

8. Arung, E.T.; Furuta, S.; Sugamoto, K.; Shimizu, K.; Ishikawa, H.; Matsushita, Y.-I.; Kondo, R. The inhibitory effects of representative chalcones contained in Angelica keiskei on melanin biosynthesis in B16 melanoma cells. Nat. Prod. Commun. 2012, 7, 1007-1010. [CrossRef]

9. Zhang, C.; Wu, W.; Li, X.; Xin, X.; Liu, D. Daily supplementation with fresh Angelica keiskei juice alleviates high-fat diet-induced obesity in mice by modulating gut microbiota composition. Mol. Nutr. Food Res. 2019, 63, 1900248. [CrossRef]

10. Kim, D.W.; Curtis-Long, M.J.; Yuk, H.J.; Wang, Y.; Song, Y.H.; Jeong, S.H.; Park, K.H. Quantitative analysis of phenolic metabolites from different parts of Angelica keiskei by HPLC-ESI MS/MS and their xanthine oxidase inhibition. Food Chem. 2014, 153, 20-27. [CrossRef]

11. Sumiyoshi, M.; Taniguchi, M.; Baba, K.; Kimura, Y. Antitumor and antimetastatic actions of xanthoangelol and 4-hydroxyderricin isolated from Angelica keiskei roots through the inhibited activation and differentiation of M2 macrophages. Phytomedicine 2015, 22, 759-767. [CrossRef]

12. Kimura, Y.; Taniguchi, M.; Baba, K. Antitumor and antimetastatic activities of 4-hydroxyderricin isolated from Angelica keiskei roots. Planta Med. 2004, 70, 211-219.

13. Zhang, T.; Wang, Q.; Fredimoses, M.; Gao, G.; Wang, K.; Chen, H.; Wang, T.; Oi, N.; Zykova, T.A.; Reddy, K. The ashitaba (Angelica keiskei) chalcones 4-hydroxyderricin and xanthoangelol suppress melanomagenesis by targeting BRAF and PI3K. Cancer Prev. Res. 2018, 11, 607-620. [CrossRef]

14. Lee, H.; Li, H.; Kweon, M.; Choi, Y.; Kim, M.J.; Ryu, J.-H. Isobavachalcone from Angelica keiskei inhibits adipogenesis and prevents lipid accumulation. Int. J. Mol. Sci. 2018, 19, 1693. [CrossRef]

15. Wang, M.; Lin, L.; Lu, J.-J.; Chen, X. Pharmacological review of isobavachalcone, a naturally occurring chalcone. Pharmacol. Res. Commun. 2021, 165, 105483. [CrossRef]

16. Wu, D.; Wang, W.; Chen, W.; Lian, F.; Lang, L.; Huang, Y.; Xu, Y.; Zhang, N.; Chen, Y.; Liu, M. Pharmacological inhibition of dihydroorotate dehydrogenase induces apoptosis and differentiation in acute myeloid leukemia cells. Haematologica 2018, 103, 1472. [CrossRef]

17. Cao, H.; Chen, X.; Jassbi, A.R.; Xiao, J. Microbial biotransformation of bioactive flavonoids. Biotechnol. Adv. 2015, 33, 214-223. [CrossRef]

18. Chen, G.; Yang, M.; Nong, S.; Yang, X.; Ling, Y.; Wang, D.; Wang, X.; Zhang, W. Microbial transformation of 20 (S)-protopanaxadiol by Absidia corymbifera. Cytotoxic activity of the metabolites against human prostate cancer cells. Fitoterapia 2013, 84, 6-10. [CrossRef]

19. Farooq, R.; Hussain, N.; Yousuf, S.; Ahmad, M.S.; Choudhary, M.I. Microbial transformation of mestanolone by Macrophomina phaseolina and Cunninghamella blakesleeana and anticancer activities of the transformed products. RSC Adv. 2018, 8, 21985-21992. [CrossRef]

20. Akihisa, T.; Motoi, T.; Seki, A.; Kikuchi, T.; Fukatsu, M.; Tokuda, H.; Suzuki, N.; Kimura, Y. Cytotoxic activities and anti-tumorpromoting effects of microbial transformation products of prenylated chalcones from Angelica keiskei. Chem. Biodivers. 2012, 9, 318-330. [CrossRef]

21. Kozłowska, J.; Potaniec, B.; Żarowska, B.; Anioł, M. Microbial transformations of $4^{\prime}$-methylchalcones as an efficient method of obtaining novel alcohol and dihydrochalcone derivatives with antimicrobial activity. RSC Adv. 2018, 8, 30379-30386. [CrossRef] 
22. Kim, H.J.; Yim, S.-H.; Han, F.; Kang, B.Y.; Choi, H.J.; Jung, D.-W.; Williams, D.R.; Gustafson, K.R.; Kennelly, E.J.; Lee, I.-S. Biotransformed metabolites of the hop prenylflavanone isoxanthohumol. Molecules 2019, 24, 394. [CrossRef] [PubMed]

23. Rong, Y.; Wu, J.; Liu, X.; Zhao, B.; Wang, Z. Study on structural and spectral properties of isobavachalcone and 4-hydroxyderricin by computational method. Spectrochim. Acta A Mol. Biomol. Spectrosc. 2014, 126, 254-259. [CrossRef] [PubMed]

24. Kim, J.H.; Son, Y.K.; Kim, G.H.; Hwang, K.H. Xanthoangelol and 4-hydroxyderricin are the major active principles of the inhibitory activities against monoamine oxidases on Angelica keiskei K. Biomol. Ther. 2013, 21, 234. [CrossRef] [PubMed]

25. Shin, J.E.; Choi, E.J.; Jin, Q.; Jin, H.-G.; Woo, E.-R. Chalcones isolated from Angelica keiskei and their inhibition of IL-6 production in TNF- $\alpha$-stimulated MG-63 cell. Arch. Pharm. Res. 2011, 34, 437-442. [CrossRef] [PubMed]

26. Clark, A.M.; McChesney, J.D.; Hufford, C.D. The use of microorganisms for the study of drug metabolism. Med. Res. Rev. 1985, 5, 231-253. [CrossRef] [PubMed]

27. Mosmann, T. Rapid colorimetric assay for cellular growth and survival: Application to proliferation and cytotoxicity assays. $J$. Immunol. Methods 1983, 65, 55-63. [CrossRef]

28. Vincent, J.; Hearing, J. Mammalian monophenol monooxygenase (tyrosinase): Purification, properties, and reactions catalyzed. Methods Enzymol. 1987, 142, 154-165.

29. Deering, R.W.; Chen, J.; Sun, J.; Ma, H.; Dubert, J.; Barja, J.L.; Seeram, N.P.; Wang, H.; Rowley, D.C. N-acyl dehydrotyrosines, tyrosinase inhibitors from the marine bacterium Thalassotalea sp. PP2-459. J. Nat. Prod. 2016, 79, 447-450. [CrossRef]

30. Kaennakam, S.; Sukandar, E.R.; Rassamee, K.; Siripong, P.; Tip-pyang, S. Cytotoxic chalcones and isoflavones from the stems of Dalbergia velutina. Phytochem. Lett. 2019, 31, 187-191. [CrossRef]

31. Roslund, M.U.; Tähtinen, P.; Niemitz, M.; Sjöholm, R. Complete assignments of the ${ }^{1} \mathrm{H}$ and ${ }^{13} \mathrm{C}$ chemical shifts and $\mathrm{J}_{\mathrm{H}, \mathrm{H}}$ coupling constants in NMR spectra of D-glucopyranose and all D-glucopyranosyl-D-glucopyranosides. Carbohydr. Res. 2008, 343, 101-112. [CrossRef]

32. Ninomiya, M.; Efdi, M.; Inuzuka, T.; Koketsu, M. Chalcone glycosides from aerial parts of Brassica rapa L. 'hidabeni', turnip. Phytochem. Lett. 2010, 3, 96-99. [CrossRef]

33. Cioffi, G.; Escobar, L.M.; Braca, A.; De Tommasi, N. Antioxidant chalcone glycosides and flavanones from Maclura (Chlorophora) tinctoria. J. Nat. Prod. 2003, 66, 1061-1064. [CrossRef]

34. Kumazawa, S.; Suzuki, S.; Ahn, M.-R.; Kamihira, M.; Udagawa, Y.; Bang, K.-S.; Nakayama, T. A new chalcone from propolis collected on Jeju island, Korea. Food Sci. Technol. 2006, 12, 67-69. [CrossRef]

35. Sugamoto, K.; Matsusita, Y.-i.; Matsui, K.; Kurogi, C.; Matsui, T. Synthesis and antibacterial activity of chalcones bearing prenyl or geranyl groups from Angelica keiskei. Tetrahedron 2011, 67, 5346-5359. [CrossRef]

36. Baba, K.; Nakata, K.; Taniguchi, M.; Kido, T.; Kozawa, M. Chalcones from Angelica keiskei. Phytochemistry 1990, $29,3907-3910$. [CrossRef]

37. Shanu-Wilson, J.; Evans, L.; Wrigley, S.; Steele, J.; Atherton, J.; Boer, J. Biotransformation: Impact and application of metabolism in drug discovery. ACS Med. Chem. Lett. 2020, 11, 2087-2107. [CrossRef]

38. Decker, H.; Schweikardt, T.; Tuczek, F. The first crystal structure of tyrosinase: All questions answered? Angew. Chem. Int. Ed. 2006, 45, 4546-4550. [CrossRef]

39. Burestedt, E.; Narvaez, A.; Ruzgas, T.; Gorton, L.; Emnéus, J.; Domínguez, E.; Marko-Varga, G. Rate-limiting steps of tyrosinasemodified electrodes for the detection of catechol. Anal. Chem. 1996, 68, 1605-1611. [CrossRef]

40. Chang, T.-S. An updated review of tyrosinase inhibitors. Int. J. Mol. Sci. 2009, 10, 2440-2475. [CrossRef]

41. Nerya, O.; Musa, R.; Khatib, S.; Tamir, S.; Vaya, J. Chalcones as potent tyrosinase inhibitors: The effect of hydroxyl positions and numbers. Phytochemistry 2004, 65, 1389-1395. [CrossRef] [PubMed] 